\title{
Development, photosynthesis and yield of blueberry cultivar 'Climax' growth with different substrates and nitrogen fertilization under protected cultivation
}

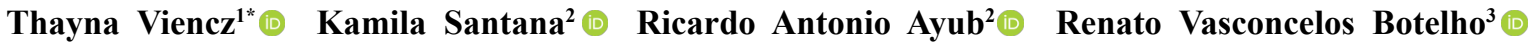 \\ ${ }^{1}$ Universidade Estadual de Londrina (UEL), 86057-970, Londrina, PR, Brasil. E-mail: thayviencz@hotmail.com. "Corresponding author. \\ ${ }^{2}$ Departamento de Fitotecnia, Universidade Estadual de Ponta Grossa (UEPG), Ponta Grossa, PR, Brasil. \\ ${ }^{3}$ Departamento de Agronomia, Universidade Estadual do Centro Oeste (UNICENTRO), Guarapuava, PR, Brasil.
}

ABSTRACT: Organic farming techniques gained popularity recently. Despite this increasing demand, there are still many problems, when comparing nutrient sources in organic and conventional farming systems. The study had as objective to evaluate the development of blueberry plants cultivar 'Climax' under protected cultivation in a substrate with different proportions of organic material and doses of applied mineral $N$. The blueberry nursery plants 'Climax' were transplanted into plastic pots and kept under protected cultivation. The soil and sand proportions were 40 and $20 \%$, respectively, of the volume capacity of each pot. The remaining $40 \%$ were filled with organic material (bovine manure) and sawdust in the proportions of 5 and 35\% (S1), 20 and $20 \%$ (S2) or 35 and $5 \%$ (S3), respectively. The experimental design was in complete randomized blocks, and the treatments were distributed in a $3 \times 3$ factorial arrangement, with six replications. The first factor was the different formulations of substrates. The second factor was $\mathrm{N}$ fertilization at 0,10 , and $15 \mathrm{~g} \mathrm{~N}$ plant ${ }^{-1}$. Evaluations of canopy volume, total leaf area, chlorophyll content and gas exchanges were performed six and eighteen months after transplanting. Fruits were harvested according to their ripening. Higher proportions of organic material in the substrate showed a substantial increase on estimated leaf area, canopy volume, chlorophyll content and clear efficiency of carboxylation $(\mathrm{A} / \mathrm{C}$ i), especially in plants that was not fertilized with mineral $N$. The highest yield was reported for the substrate $S 2$, with intermediary amount of organic material, without the application of mineral $N$ fertilizer. Considering agronomic and physiological traits, blueberry plants on the substrate $S 2(20 \%$ OM) showed the best results, without mineral $N$ fertilizing, becoming viable the organic management system for potted 'Climax' blueberry plants under protected cultivation.

Key words: Vaccinium spp., plant nutrition, gas exchange, chlorophyll, fruits, organic production.

Fotossíntese, desenvolvimento e produtividade de mirtileiros cultivar 'Climax' cultivados com diferentes substratos e fertilizantes nitrogenados sob cultivo protegido

RESUMO: As técnicas de manejo orgânico ganharam popularidade recentemente. Apesar deste aumento da demanda, ainda há muitos problemas, quando se comparam fontes de nutrientes para manejo orgânico e convencional. O estudo objetivou avaliar o desenvolvimento de mirtileiro cultivar 'Climax'sob cultivo protegido em substrato com diferentes proporções de matéria orgânica e doses de $\mathrm{N}$ mineral. As mudas de mirtileiro 'Climax' foram transplantadas para vasos plásticos e mantidas sob cultivo protegido. As proporções de solo e areia foram de 40 e 20\%, respectivamente, da capacidade de volume de cada vaso. Os $40 \%$ restantes foram preenchidos com matéria orgânica (esterco bovino) e serragem de madeira nas proporções de 5 e 35\% (S1), 20 e 20\% (S2) e 35 e 5\% (S3), respectivamente. O desenho experimental foi em blocos completamente casualizados em esquema fatorial 3x3, com seis repetições. O primeiro fator foram as diferentes formulações de substrato. $O$ segundo fator foi a adubação nitrogenada a 0,10 , e $15 \mathrm{~g} \mathrm{~N}$ planta ${ }^{-1}$. Avaliações de volume de copa, área foliar total, conteúdo de clorofila e trocas gasosas foram realizadas aos seis e dezoito meses após o transplante. Os frutos foram colhidos de acordo com a maturação. Maiores proporções de matéria orgânica no substrato mostraram um aumento substancial na área foliar estimada, volume de copa, teor de clorofila e na eficiência aparente de carboxilação (A/Ci), especialmente, em plantas que não foram adubadas com $N$ mineral. A maior produtividade foi verificada para o substrato $S 2$, com quantidade intermediária de matéria orgânica, sem a aplicação de fertilizante mineral N. Considerando as características agronômicas e fisiológicas, plantas de mirtileiro no substrato $S 2$ (20\% MO) apresentou melhores resultados, sem adubação com $N$ mineral, tornando viável o sistema de manejo orgânico para plantas envasadas de mirtileiro 'Climax'sob cultivo protegido.

Palavras-chave: Vaccinium spp., nutrição de plantas, fotossíntese, frutos, produção orgânica.

\section{INTRODUCTION}

The blueberry is a deciduous fruit plant belonging to the family Ericaceae and genus Vaccinium. More than 400 species are included in this genus and approximately $40 \%$ of them are native to Southeast Asia, 25\% from North America and 10\% from Central and South America (DARNELL, 2006). It is a crop that grows on soils with low $\mathrm{pH}$, good drainage, but requires moderate humidity (SANTOS; RASEIRA, 2002). 
The blueberry 'Climax' is a variety from the "rabbit eye group," classified as a vigorously fruit-bearing plant that is naturally heat tolerant. It is a blueberry bush that produces early in the season with a high yield of large and dark blue berries. Its chilling requirement is between 400 and $450 \mathrm{~h}\left(\leq 7.2^{\circ} \mathrm{C}\right)$ (BRASWELL, 2009).

In 2008, the Brazilian cultivated area of blueberry plants was approximately 150 hectares (FACHINELLO, 2008). CANTUARIAS-AVILÉS et al. (2014) estimated that the cultivated area of blueberry is approximately 400 ha in Brazil; although, official statistics do not exist. In the country, much of the production is destined for export and part is consumed by the domestic market. According to the same authors, among the Brazilian states, Rio Grande do Sul, Santa Catarina, Paraná, São Paulo and Minas Gerais concentrate the largest cropping areas.

Organic production system has gained popularity in recently as a result of increasing consumer demand for organic products and the necessity for soil conservation. Organic permanent crops represent $2.5 \%$ of the world's permanent cropland (4 million ha) and $8 \%$ of the organic agricultural land with an increase of 19\% over 2014 (IFOAM, 2017). Despite this increasing demand, there are still many problems in organic crop management, such as control of diseases and pests without synthetic pesticides, for example. Another important limitation for organic farming is the availability of allowed fertilizers. There is a great difficulty in controlling all the variables when nutrient sources of organic and conventional farming systems are compared (LESTER, 2006).

Protected cultivation can become organic farming easier. Tunnels and greenhouses are used for protection from the elements, environmental modification, or season extension. Frequently, the methods recommended for growing small fruit crops under protected cultivation are similar to those recommended for field production with relatively minor changes in irrigation timing, amount, and type; fertilization methods; and pruning techniques. Pesticide usage may be markedly decreased; however, and biological or cultural controls can play a significant role in pest management. Less frequently, plants are grown in containers that may be pots for raspberry, or table-top or gutter systems in the case of strawberry (DEMCHAK, 2009).

The supply of $\mathrm{N}$ via fertilizers is a fundamental practice to obtain high yields in most crops (FAQUIN, 2005). Nevertheless, many biological and chemical processes cause first-year recovery by plants to be generally less than $50 \%$ of the applied $\mathrm{N}$. Low $\mathrm{N}$ efficiency can also be caused by an imbalance of other essential plant nutrients. Nitrogen management is also made difficult due to uncertainties related to weather events following fertilization (MIKKELSEN; HARTZ, 2008).

In high bush blueberry, plants fertilized with $50 \mathrm{~kg} \mathrm{~N} \mathrm{ha}^{-1}$ produced $22-32 \%$ more dry weight (DW) in the first season and $78-90 \%$ more DW in the second season than unfertilized plants or plants fertilized with $100 \mathrm{~kg} \mathrm{~N} \mathrm{ha}^{-1}$. Overall, plants fertilized with $50 \mathrm{~kg} \mathrm{~N} \mathrm{ha}^{-1}$ produced the most growth and, from planting to the first fruit harvest, required 34.8 $\mathrm{kg} \mathrm{N} \mathrm{ha}{ }^{-1}, 2.3 \mathrm{~kg} \mathrm{Pha}^{-1}, 12.5 \mathrm{~kg} \mathrm{~K} \mathrm{ha}^{-1}, 8.4 \mathrm{~kg} \mathrm{Ca} \mathrm{ha}^{-1}$, $3.8 \mathrm{~kg} \mathrm{Mg} \mathrm{ha}^{-1}, 5.9 \mathrm{~kg} \mathrm{~S}^{-1}, 295 \mathrm{~g} \mathrm{Fe} \mathrm{ha}^{-1}, 40 \mathrm{~g} \mathrm{~B}$ $\mathrm{ha}^{-1}, 23 \mathrm{~g} \mathrm{Cu} \mathrm{ha}^{-1}, 1273 \mathrm{~g} \mathrm{Mn} \mathrm{ha}^{-1}$, and $65 \mathrm{~g} \mathrm{Zn} \mathrm{ha}^{-1}$ (BRYLA et al., 2012). In Brazil, under field conditions, the recommendation for blueberry fertilization in the conventional system is to apply in the first and second year after planting, 10 and $15 \mathrm{~g} \mathrm{~N}$ plant $^{-1}$, respectively. Additionally, 16 to $24 \mathrm{t} \mathrm{ha}^{-1}$ of cattle manure is also suggested (ANTUNES; RASEIRA, 2006).

Since the use of manufactured $\mathrm{N}$ fertilizer is not allowed for organic production, the search for other sources is required. Nevertheless, unlike other plant nutrients (such as $\mathrm{P}$ and $\mathrm{K}$ ), there is no universal or widely used soil test to predict the amount of supplemental $\mathrm{N}$ required to meet the crop's need. Instead, the need for $\mathrm{N}$ supplementation is typically based on yield expectations, field history, and measurement of residual $\mathrm{NO}^{3-}$. Nutrients in commercial fertilizers are soluble, so their availability to plants is predictable. However, most organic $\mathrm{N}$ sources require mineralization (conversion to inorganic forms) before they can be used by plants. Environmental factors such as soil temperature, $\mathrm{pH}$, moisture, and management practices such as tillage intensity, all impact the rate of $\mathrm{N}$ availability from organic sources (MIKKELSEN; HARTZ, 2008).

Manure is a complex material that contains valuable nutrients and potential pollutants. This source of essential plant nutrients and organic matter is often is used to build and maintain soil fertility and increase the soil's water-holding capacity (FOLLET; CROISSANT, 1992). The manure $\mathrm{N}$ is present in both organic and inorganic forms. Nitrogen is unstable in fresh manure because ammonia $\left(\mathrm{NH}_{3}\right)$ can be readily lost through volatilization. The organic $\mathrm{N}$-containing compounds in manure become available for plant uptake following mineralization by soil microorganisms, while the inorganic $\mathrm{N}$ fraction is immediately available (MIKKELSEN; HARTZ, 2008).

The blueberry is a plant that has a thin, fibrous roots and few of them are absorbents 
(DARNELL, 2006). To compensate for this low nutrient uptake by the roots, one of the methods to increase the capacity of retention in the soil would be the addition of organic material that is responsible for improving certain soil physical properties such as macroaggregation, porosity and better water infiltration, as well as increasing the cation exchange capacity (BALESDENT et al., 2000). In plants, Vaccinium corymbosum yield and chlorophyll content were higher in plants treated with organic fertilizers such as lupine meal, blood meal and purely grow (MUÑOZ-VEGA et al., 2016).

Considering all these aspects discussed above, some questions are specified, such as if there is the possibility of cultivating blueberry-potted plants in greenhouses in a more sustainable system with lower economic risks and without synthetic inputs. Moreover, it would be of interest to see how the amount of organic fertilizer influences plant growth and yield. Moreover, it is important to know how much this source could substitute $\mathrm{N}$ mineral fertilizer.

This study evaluated the development of blueberry plants 'Climax' under protected cultivation in substrate with different proportions of organic material and doses of applied mineral $\mathrm{N}$.

\section{MATERIALS AND METHODS}

The experiment was conducted in Ponta Grossa, State of Paraná, Brazil $\left(25^{\circ} 05^{\prime} 23.2^{\prime}\right.$ 'S, $50^{\circ} 06$ '09.2”'W, $975 \mathrm{~m}$ altitude) from July 2014 to June 2016. The one-year blueberry nursery plants 'Climax' were transplanted into plastic pots with dimensions of $36 \mathrm{~cm}$ in diameter and $26 \mathrm{~cm}$ in height. The pots were spaced in $40 \mathrm{~cm}$ and kept in a greenhouse with intermittent irrigation. This structure was fully enclosed with double transparent plastic (to provide thermal insulation) and control temperature $\left(25^{\circ} \mathrm{C}\right)$. After planting, the stem was pruned $20 \mathrm{~cm}$ above the soil surface.

The three substrates prepared were composed by different proportions of a mixture composed by soil, sand, sawdust and organic material. The soil corresponded to the deep layer (2 m) of a Distroferric Red Latosol (EMBRAPA, 2006) that was sieved in a $4 \mathrm{~mm}$ mesh. The attributes of this soil were $188.4 \mathrm{~g} \mathrm{~kg}^{-1}$ sand; $91.6 \mathrm{~g} \mathrm{~kg}^{-1}$ silt and $720 \mathrm{~g}$ $\mathrm{kg}^{-1}$ clay; $\mathrm{pH}\left(\mathrm{CaCl}_{2}\right)=4.7 ; \mathrm{H}+\mathrm{Al}=4.28 \mathrm{mmol} \mathrm{dm}^{-3}$; $\mathrm{Al}=0.2 \mathrm{mmol} \mathrm{dm}^{-3} ; \mathrm{Ca}=1.0 \mathrm{mmol} \mathrm{dm}^{-3} ; \mathrm{Mg}=1.1$ mmolc dm ${ }^{-3} ; \mathrm{K}=0.14 \mathrm{mmol} \mathrm{dm}^{-3} ; \mathrm{P}=0.3 \mathrm{mg} \mathrm{dm}^{-3}$, organic $\mathrm{C}=12 \mathrm{~g} \mathrm{dm}^{-3}, \mathrm{CTC} \mathrm{pH} 7.0=6.52 \mathrm{cmolc} \mathrm{dm}^{-3}$ and base saturation $=34.4 \%$.
The soil and sand proportions were 40 and $20 \%$; respectively, of the volume capacity of each pot $(9.4 \mathrm{~L})$. The remaining $40 \%$ were filled with organic material (bovine manure) and sawdust in the proportions of $5 \%$ organic material and $35 \%$ sawdust (S1), 20\% OM and 20\% sawdust (S2) and 35\% OM $+5 \%$ sawdust (S3).

The experimental design was in a factorial scheme $3 \times 3$ ( $\mathrm{N}$ doses $\mathrm{x}$ substrates) in a completely randomized block, with six replications and one-plant plot. The treatments were different formulations of substrates and $\mathrm{N}$ fertilization at 0,10 , and $15 \mathrm{~g} \mathrm{~N}$ plant $^{-1}$

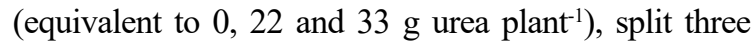
times each year (August, September and October).

Growth assessments, total leaf area, chlorophyll content and gas exchanges were performed in January 2015 and January 2016, six and eighteen months after transplanting, respectively.

Plant height $(\mathrm{cm})$ was measured from the plant neck to the apex of the plant; as well as the distance measurements between the main branches and crown diameter. To measure the diameter of the main branches, a digital caliper was used.

The volume of the canopy of the plants was calculated using the formula $\mathrm{V}=[(\mathrm{L} / 2) \times(\mathrm{E} / 2)$ $\times \mathrm{A} \times \pi] / 3$, where $\mathrm{V}$ is the canopy volume, $\mathrm{L}$ is the distance between the main branches, $\mathrm{E}$ is the average thickness or diameter of the main branches and $\mathrm{A}$ is the crown height (ROSSI, 2004). The distance L was measured by stretching the tape measure from one extreme to another of the main branches farthest from each other in a line perpendicular to the plant.

The leaf area was calculated from the average of ten leaves randomly collected and obtained with the use of an area-meter, model LI 3000 (LI-COR BIOSCIENCES, Lincoln, NE, USA). The mean leaf area per leaf was multiplied by the total number of leaves counted in each plant at the time of collection to obtain the total leaf area.

The determination of the values of total chlorophyll were performed using the chlorophyll meter, brand ClorofiLOG ${ }^{\circledR}$, model CFL 1030 (FALKER, Porto Alegre, RS, Brazil). The chlorophyll meter reading was performed in three leaves, one in each third of the plant and counted the average, being an older leaf, a newly mature leaf, and a younger leaf.

The gas exchange indexes were obtained using a portable infrared $\mathrm{CO}_{2}$ analyzer model LI6400XT (LI-COR, INC., Lincoln, NE, USA). Measurements were performed between 11 and $14 \mathrm{~h}$, using three leaves per plot, one older (more rigid), one medium (in full photosynthetic activity) and one younger (leaf apices with area greater than $4 \mathrm{~cm}^{2}$ ). 
The concentration of $400 \mathrm{~mol}^{-1}$ of $\mathrm{CO}_{2}$ within the chamber and the photosynthetically active photon flux density of $1000 \mu \mathrm{mol} \mathrm{m} \mathrm{m}^{-2} \mathrm{~s}^{-1}$ were used as the standard for all measurements, using light source LICOR 6400-02 coupled to measuring chamber. The temperature inside the chamber was set at $20^{\circ} \mathrm{C}$. The estimated indexes were as follows: photosynthesis (A), stomatal conductance (gS), transpiration rate (E), intercellular $\mathrm{CO}_{2}$ concentration $(\mathrm{Ci})$, relationship between the concentration of intercellular and atmospheric $\mathrm{CO}_{2}(\mathrm{Ci} / \mathrm{A})$. From the measurements of $\mathrm{A}, \mathrm{Ci}, \mathrm{gS}$, and $\mathrm{E}$, the following estimated indexes were obtained: the clear efficiency of carboxylation $(\mathrm{A} / \mathrm{Ci})$, the intrinsic water use efficiency $(\mathrm{A} / \mathrm{gS})$ and the instantaneous water use efficiency $(\mathrm{A} / \mathrm{E})$.

Fruits were harvested according to their ripening (dark color of the skin) between December 2015 and March 2016. The total number of fruits per plant, mean fruit weight and yield per plant were computed.

Results were submitted to analysis of variance and comparison between means by the Student Newman-Keuss $(p \leq 0.05)$ using software Sisvar 5.0 (FERREIRA, 2011).

\section{RESULTS AND DISCUSSION}

Results of leaf area of blueberry plants 'Climax' presented interactions between factors in both years (Figures 1A and 1B). The lowest leaf area was always observed for the plants in the substrate $\mathrm{S} 1(5 \% \mathrm{OM})$ and without $\mathrm{N}$ fertilizer. $\mathrm{N}$ application significantly increased the leaf area of plants in substrate $\mathrm{S} 1(5 \% \mathrm{OM})$ in both years. Moreover, the highest leaf area was reported for the treatments S2 (20\% OM) $+10 \mathrm{~g} \mathrm{~N}$ plant ${ }^{-1}$ and S3 (35\% OM) + $15 \mathrm{~g} \mathrm{~N}$ plant $^{-1}$, in the first and second year, respectively. Similarly, effects of treatments on canopy volume were also significant, but the interaction was observed only in the first year (Figures 1C and 1D). In fact, the higher the organic material content (bovine manure) in the substrate, the higher the volume of the canopy. The application of $\mathrm{N}$ also favored the development of the plants, but differences between the doses of 10 and $15 \mathrm{~g} \mathrm{~N}$ plant ${ }^{-1}$ were not evident considering the two years.

The addition of a higher proportion of organic material in the substrate for blueberry 'Climax' under protected cultivation showed a substantial increase on the growth of the plants, represented by the increments on the estimated leaf area and canopy volume, especially in plants that was not fertilized with mineral N (Figure 1). Nitrogen fertilizer also affected these plant traits, improving the growth, mostly in the substrate with the lower proportion of organic material (S1 - 5\% OM), but the differences between the doses of 10 and $15 \mathrm{~g} \mathrm{~N}$ plant $^{-1}$ was not always evident.

The blueberry is a plant that has thin, fibrous roots and few of them are absorbents (DARNELL, 2006) and according to BALESDENT et al. (2000), one of the methods to increase the capacity of plant uptake and availability of nutrients is the addition of organic material that is responsible for improving certain soil physical properties such as macroaggregation, porosity and water infiltration, as well as increasing cation exchange capacity and nutrient availability. BURKHARD et al. (2009) conducted a 2-year study in Nova Scotia examining the effectiveness of thickly applied organic mulches as a method of weed control in highbush blueberries (Vaccinium corymbosum L.). These authors reported that mulches of manure-sawdust compost applied inrow at 20-cm depth, improved significantly plant vigor and yield and increased leaf tissue elemental (NPK) composition. According to SOUSA and RESENDE (2006), bovine manure is a significant source of nutrients and contains in its composition $5.0 \% \mathrm{~N}, 2.5 \%$ $\mathrm{P}$ and $5.0 \% \mathrm{~K}$ (dry matter), besides other elements, important for plant nutrition and vegetative growth.

The effect of $\mathrm{N}$ fertilizers on growth of plants is well known. Nitrogen occupies a conspicuous place in plant metabolism system. All vital processes in plants are associated with protein, of which $\mathrm{N}$ is an essential constituent. All plants including cereals, oilseeds, fiber, and sugar producing require a balanced amount of $\mathrm{N}$ for vigorous growth and development that ensures the greatest harvest with better quality (LEGHARI et al., 2016). In highbush blueberry, plants fertilized with $50 \mathrm{~kg} \mathrm{~N}$ ha $^{-1}$ produced $22-32 \%$ more dry weight (DW) in the first season and $78-90 \%$ more DW in the second season than unfertilized plants or fertilized with $100 \mathrm{~kg} \mathrm{~N} \mathrm{ha}^{-1}$ (BRYLA et al., 2012).

Total chlorophyll in leaves was also influenced substantially by the organic material proportion in the substrate and $\mathrm{N}$ application in the second year (Figures 1E and 1F). Generally, the higher the organic material proportion, higher the chlorophyll content in leaves of blueberry plants. Nitrogen application also affected total chlorophyll and the highest value was found for the plants in the substrate S3 $(35 \% \mathrm{OM})$ with the application of 10 or $15 \mathrm{~g} \mathrm{~N}$ plant $^{-1}$. Similarly, MUÑOZ-VEGA et al. (2016) reported that chlorophyll content was higher in plants of Vaccinium corymbosum treated with organic fertilizers such as lupine meal, blood meal and purely growth; or fertilized with urea. Also, many investigators have proved a close relationship 


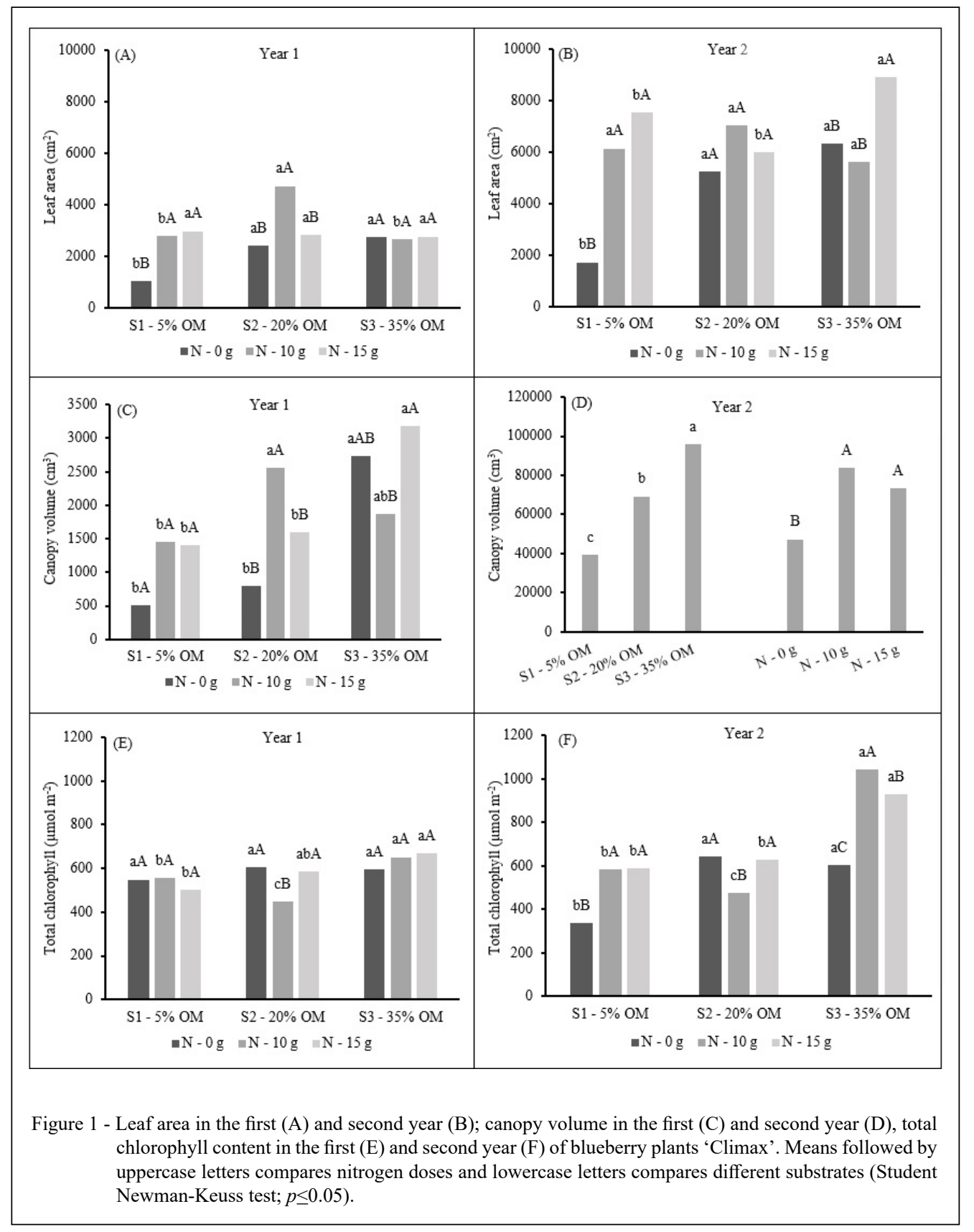

between chlorophyll and N content (EVANS, 1983; FIELD; MOONEY, 1986; AMALIOTIS et al., 2004). It is understandable because $\mathrm{N}$ is a structural element of chlorophyll and protein molecules, and thereby affecting the formation of chloroplasts and accumulation of chlorophyll in them (TUCKER, 2004; DAUGHTRY, 2000).

The effects of the factors under study on photosynthesis were different between years (Figures
2A and 2B). In the first year, plants unfertilized with $\mathrm{N}$ presented a higher photosynthesis on the substrate $\mathrm{S} 2$ (20\% OM). Moreover, blueberry plants on substrate 3 (35\% OM) present higher photosynthesis when fertilized with $15 \mathrm{~g} \mathrm{~N}$ plant $^{-1}$. In the second year, the highest photosynthesis rate was in plants on substrate 3 (35\% OM), independently of $\mathrm{N}$ fertilization.

The transpiration rate (E) also showed different patterns in the two different periods of 
evaluation. In the first year, plants on substrate S1 (5\% OM) presented the highest rate, followed by S2 (20\% OM) and S3 (35\% OM) (Figure 2C). However, in the second year, plants on S3 $(35 \%$ $\mathrm{OM}$ ) showed the highest transpiration rate (Figure 2D). Opposite effects of substrates were observed for instantaneous water use efficiency $(A / E)$. In the first year the highest value was found for S3 (35\% OM) (Figure 2E), while in the second year the highest value was for S1 (5\% OM) (Figure 2F).
Effects of substrate on the transpiration rate (E) and instantaneous water use efficiency (A/E) between the two years were clear but opposite from year to year (Figure 2). In the first year, probably the highest proportion of sawdust in the substrate S1 (5\% OM) kept the humidity higher in the root zone, increasing the transpiration rate and reducing the instantaneous water use efficiency. In the second year; however, with the decomposition of the sawdust, probably the humidity in the roots zone was not kept in the

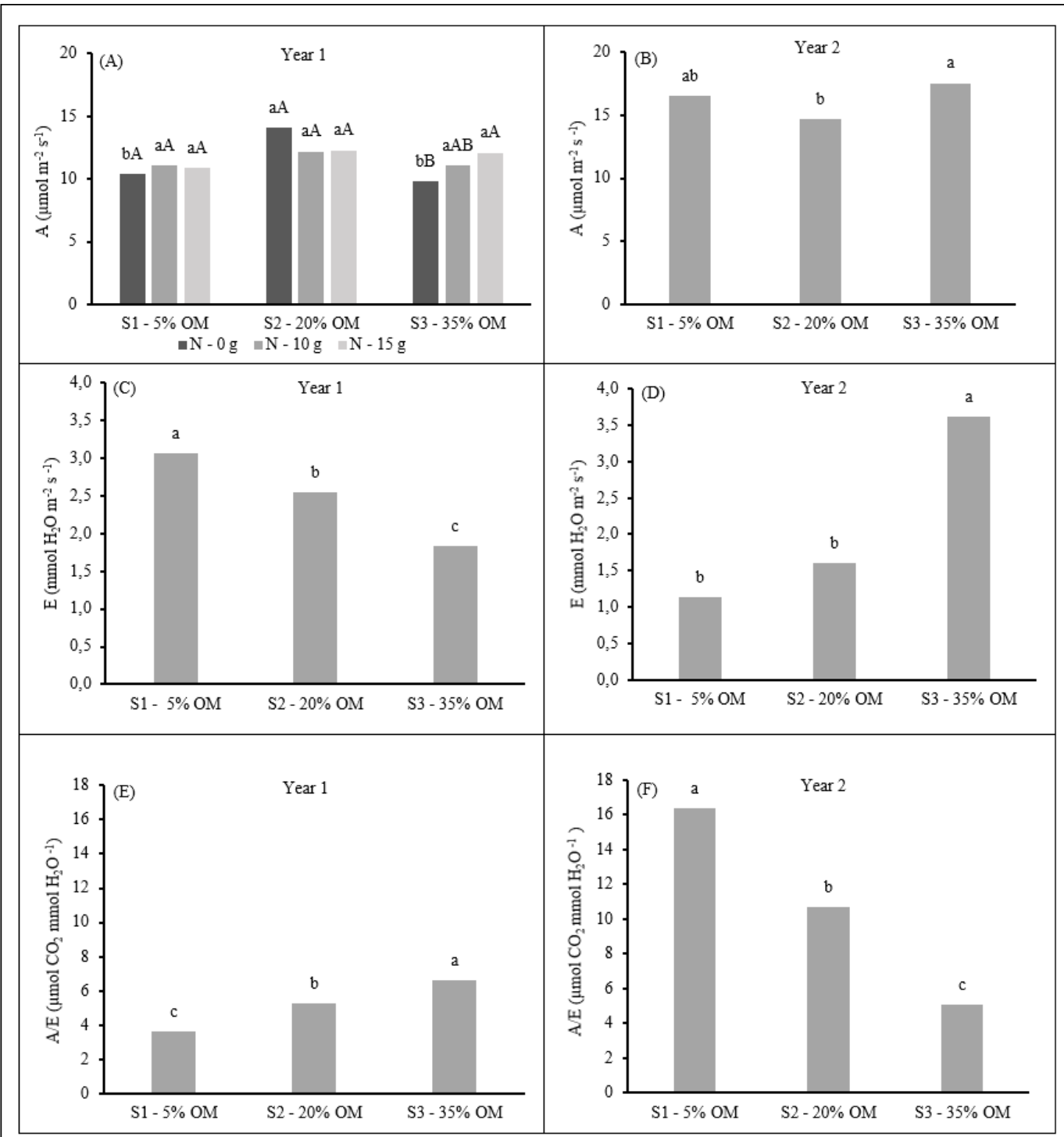

Figure 2 - Carbon assimilation rate (photosynthesis) in the first (A) and second year (B); transpiration rate in the first (C) and second year (D); instantaneous water use efficiency in the first (E) and in the second year (F) of blueberry plants 'Climax'. Means followed by uppercase letters compares nitrogen doses and lowercase letters compares different substrates (Student Newman-Keuss test; $p \leq 0.05$ ). 
same level, reducing transpiration rate and increasing the instantaneous water use efficiency. Moreover, as substrate S3 (35\% OM) promoted higher leaf area and volume canopy in the second year, and probably the highest root volume, which means the highest exploration of water, and the transpiration was also higher. This is because a plant with more root surface area will uptake more water available in the soil. More water within the plant will mean a steeper plant-toatmosphere vapor pressure gradient and more water to transpire within a duration (DEVLIN, 1975).

In relation to intercellular $\mathrm{CO}_{2}$ concentration $(\mathrm{Ci})$, the values were higher for the plants on the substrate $\mathrm{S} 1(5 \% \mathrm{OM})$ in both years (Figures 3A and 3B), independently of the applied N dose. Additionally, plants without fertilization $(0-\mathrm{g}$ $\mathrm{N}$ plant $^{-1}$ ) showed the highest intercellular carbon concentration in the second year (Figure 3B). The effect of substrates on the relationship between the concentration of intercellular and atmospheric $\mathrm{CO}_{2}$ was consistent in both years and the blueberry plants on substrate $\mathrm{S} 1$ (5\% OM) showed higher values (Figures 3C and 3D). Moreover, plants without $\mathrm{N}$ fertilization also presented the highest $\mathrm{Ci} / \mathrm{Ca}$ relationship in the second year. Likewise, blueberry plants on substrate S1 (5\% OM) showed the lowest

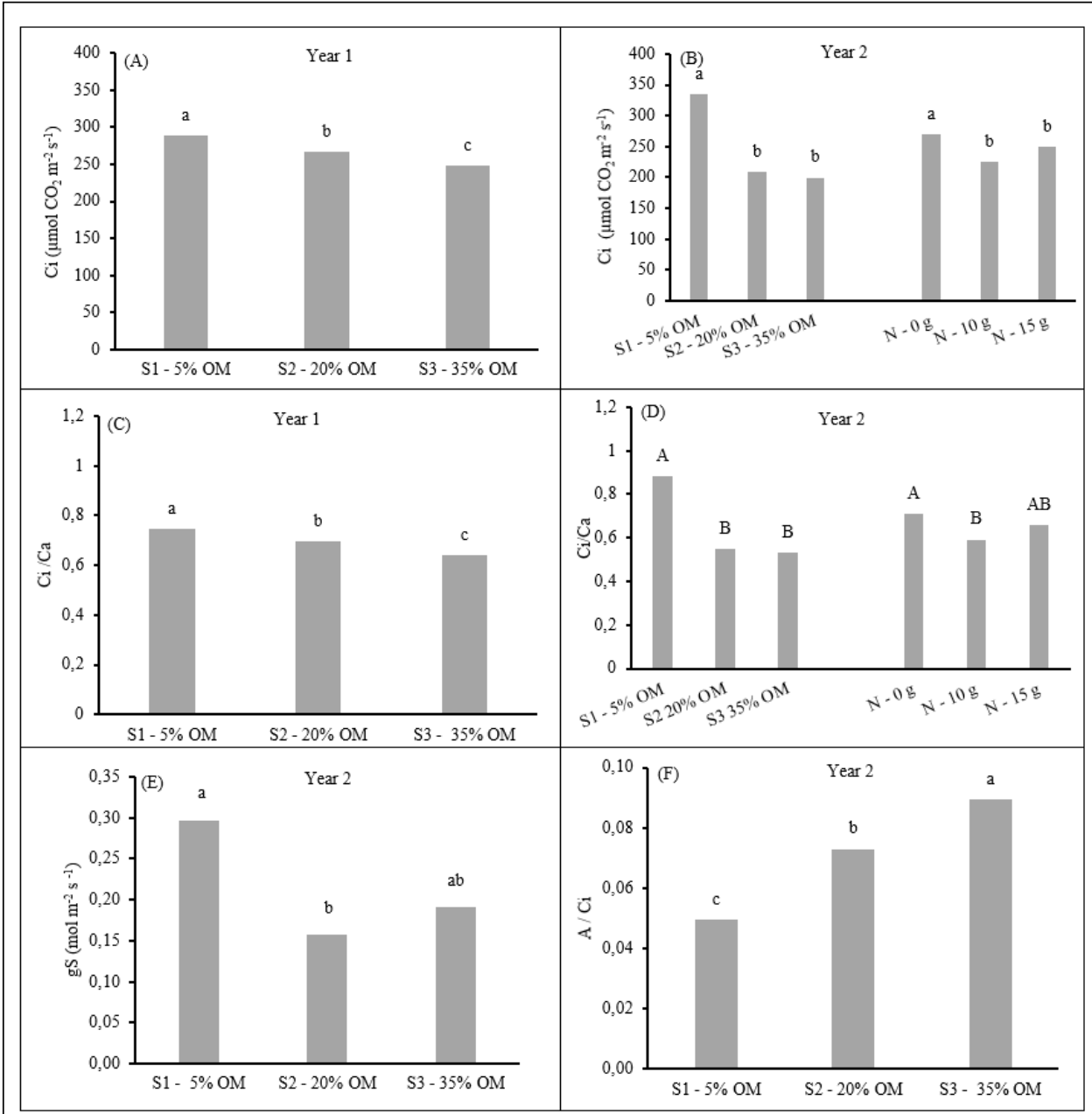

Figure 3 - Intercellular $\mathrm{CO}_{2}$ concentration in the first (A) and second year (B); relationship between the concentration of intercellular and atmospheric $\mathrm{CO}_{2}$ in the first (C) and second year (D); stomatal conductance (E) and apparent carboxylation efficiency $(\mathrm{F})$ in the second year of blueberry plants 'Climax'. Means followed by uppercase letters compares nitrogen doses and lowercase letters compares different substrates (Student Newman-Keuss test; $p \leq 0.05$ ). 
stomatal conductance (gs) (Figure 3E), and the lowest clear carboxylation efficiency (A/Ci) (Figure 3F).

The fact of the plants in substrate S3 (35\% OM) have had a much faster and strong growth of canopy (Figure 1), which could lead to a much higher proportion of young leaves; and therefore with thinner cuticles and thinner cell walls, and this could also lead to a greater loss of water (DEVLIN, 1975), even with not much greater stomatal conductance (Figure 3E).

The substrate $\mathrm{S} 1 \quad(5 \% \mathrm{OM})$ with lower organic material content lead to a higher intracellular $\mathrm{CO}_{2}$ concentration $(\mathrm{C} 1)$ and higher $\mathrm{Ci} / \mathrm{Ca}$ relation in both years. The same pattern was found for plants without mineral $\mathrm{N}$ fertilization in the second year (Figure 3). By the $\mathrm{Ci} / \mathrm{Ca}$ ratio, it is possible to verify the efficiency or inefficiency of the carbon fixation reactions, and the closer this ratio is to 1 , the less efficient this process, due to problems in the photosynthetic machinery (GUERRA et al., 2017). This can be evidenced by the significant increase in the clear efficiency of carboxylation (A/Ci) and photosynthesis rate for the substrate S3 (35\% OM) with higher organic material content (Figures $2 \mathrm{~B}$ and 3F). Similarly, YAÑEZ-MANSILLA et al. (2014) observed decreasing of $\mathrm{CO}_{2}$ assimilation for high bush blueberry cv. Legacy under $\mathrm{N}$ starvation.

No statistical differences between treatments were observed for the mean fruit weight of blueberries 'Climax' (data not shown). Effects of substrates and $\mathrm{N}$ doses showed similar patterns on many fruits and yield per plant (Figures 4A and 4B). The highest number of fruits and yields were

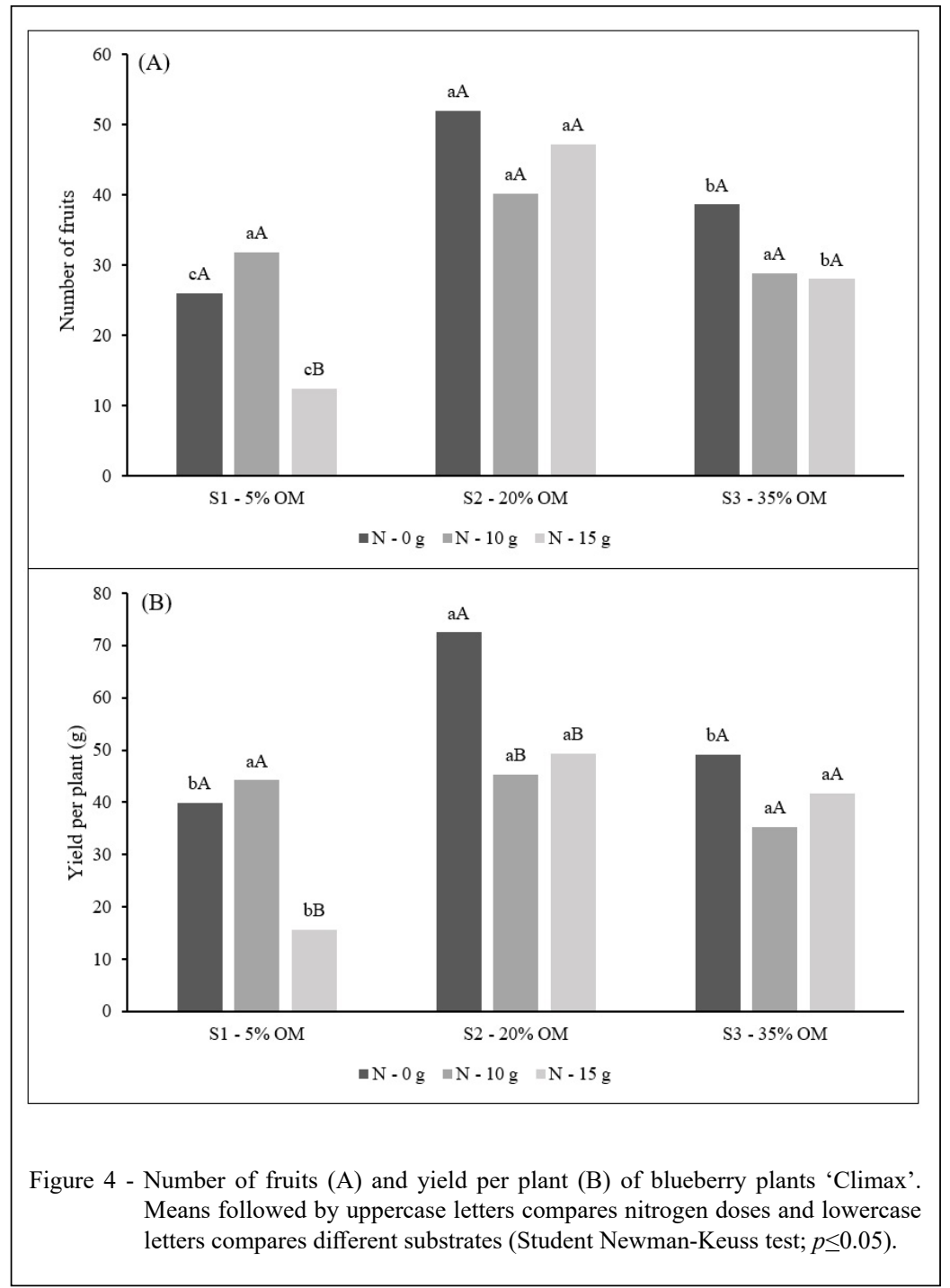

Ciência Rural, v.51, n.6, 2021. 
reported for the plants on Substrate S2 (20\% $\mathrm{OM}$ ) without $\mathrm{N}$ fertilization. The lowest values were found for blueberry plants on substrate S1 fertilized with $15 \mathrm{~g} \mathrm{~N}$ plant $^{-1}$.

The highest yield was observed for the substrate S2 (20\% OM), with intermediary amount of organic material, without the application of mineral $\mathrm{N}$ fertilizer (Figure 4B). The inverse relationship between excessive vegetative growth and fruit production is well known. GRANATH; STRENGBOM (2017) reported that $\mathrm{N}$ fertilization reduced fruit production for bilberry $(V$. myrtilus $)$ and cowberry ( $V$. vitis-idaea) in boreal forests due to an increase in the amount of resources to competitive structures and less to reproduction.

Since the use of manufactured fertilizer is not allowed for organic production, the search for other nutrient sources is required. Commercial fertilizers are soluble, so nutrient availability to plants is predictable. However, most organic sources require mineralization (conversion to inorganic forms) before they can be used by plants and many factors impact the rate of nutrient availability from organic sources (MIKKELSEN; HARTZ, 2008). Manure is a complex material that contains valuable nutrients, mainly $\mathrm{N}, \mathrm{P}$, and $\mathrm{K}$. The manure $\mathrm{N}$ is present in both organic and inorganic forms. The organic $\mathrm{N}$-containing compounds in manure become available for plant uptake following mineralization by soil microorganisms, while the inorganic $\mathrm{N}$ fraction is immediately available (MIKKELSEN; HARTZ, 2008).

Our results showed that the use of organic sources of nutrients, such as manure, can replace synthetic fertilizers, at least considering element $\mathrm{N}$ and became possible the production of blueberry in an organic system. The production of blueberry in potted plants under protected cultivation also showed great potential, considering the better control of environmental factors; and therefore less dependent on synthetic agricultural inputs.

\section{CONCLUSION}

Blueberry plants 'Climax' showed a positive response to the increment of organic matter proportion in the substrate on the leaf area, canopy volume, chlorophyll content and clear efficiency of carboxylation $(\mathrm{A} / \mathrm{Ci})$. Despite some benefits of mineral $\mathrm{N}$ fertilizer, the addition of higher content of organic material in the substrate reduced the positive effects of this chemical fertilizer. According to the results of this trial, the substrate S2 $(20 \%$ OM) showed the best vegetative and reproductive development balance, resulting in the highest yield per plant.

\section{DECLARATION OF CONFLICT OF INTERESTS}

The authors declare no conflict of interest. The funding sponsors had no role in the design of the study; in the collection, analysis, or interpretation of data; in the writing of the manuscript, and in the decision to publish the results.

\section{ACKNOWLEDGEMENTS}

We would like to thank the Coordenação de Aperfeiçoamento de Pessoal de Nível Superior (CAPES) for granting a scholarship to the first two authors.

\section{AUTHORS' CONTRIBUTIONS}

All authors contributed equally for the conception and writing of the manuscript. All authors critically revised the manuscript and approved of the final version.

\section{REFERENCES}

AMALIOTIS, D., THERIOS, I., KARATISSIOU, M. Effect of nitrogen fertilization on growth, leaf nutrient concentration and photosynthesis in three peach cultivars. Acta Horticulturae, v.449, p.36-42, 2004.

ANTUNES, L. E. C.; RASEIRA, M. C. B. Growing blueberry (Vaccinium spp). Pelotas: Embrapa Clima Temperado, 2006. 98p. (Sistema de Produção, 8)

BALESDENT, J.; CHENU, C.; BALABANE, M. Relationship of soil organic matter dynamics to physical protection and tillage. Soil and Tillage Research, v.53, n.3-4, p.215-230, 2000. Available from: <https://www.sciencedirect.com/science/article/ pii/S0167198799001075>. Accessed: Apr. 15, 2019. doi: 10.1016/ S0167-1987(99)00107-5.

BRASWELL, J. Establishment and Maintenance of Blueberries. 2009. Available from: <https://extension.msstate. edu/sites/default/files/publications/publications/p1758_0.pdf $>$. Accessed: Jun. 25, 2018.

BRYLA, D. R. et al. Response of high bush blueberry to nitrogen fertilizer during field establishment - II. Plant nutrient requirements in relation to nitrogen fertilizer supply. HortScience, v.47, n.7, p.917-926, 2012. Available from: <https://www.researchgate. net/publication/286726305 Response of Highbush Blueberry to_Nitrogen_Fertilizer_during_Field__Establishment-II_ Plant_Nutrient_Requirements_in_Relation_to_Nitrogen Fertilizer_Supply>. Accessed: Apr. 15, 2019. doi: 10.21273/ HORTSCI.47.7.917.

BURKHARD, N. et al. Organic mulch impact on vegetation dynamics and productivity of highbush blueberry under organic production. HortScience, v.44, n.3, p.688-696, 2009. Available from: $\quad<$ https://www.researchgate.net/publication/255908819 Organic Mulch Impact on Vegetation Dynamics and Productivity_of_Highbush_Blueberry_Under_Organic 
Production>. Accessed: Apr. 15, 2019. doi: 10.21273/ HORTSCI.44.3.688.

CANTUARIAS-AVILÉS, T. et al. Blueberry cultivation: upgrades and initial performance of 18 low-strain varieties in cold conditions in the state of São Paulo. Revista Brasileira de Fruticultura, v.36, n.1, p.139-147, 2014. Available from: <http://www.scielo. br/pdf/rbf/v36n1/v36n1a15.pdf $>$. Accessed: Apr. 15, 2019. doi: $10.1590 / 0100-2945-453 / 13$.

DARNELL, R. L. Blueberry botany/environmental physiology. In: CHILDERS, N. F.; LYRENE, P. M. Blueberries for growers, gardeners, promoters. Florida: E. O. Painter Printing Company, 2006. p.5-13.

DAUGHTRY, C. S. T.; et al. Estimating corn leaf chlorophyll concentration from leaf and canopy reflectance. Rem. Sens. of Environment, v.74, p.229-239, 2000.

DEMCHAK, K. Small fruit production in high tunnels HorTechnology, v.19, n.1, p.44-49, 2009. Available from: <https:// www.ishs.org/ishs-article/987_4>. Accessed: Apr. 15, 2019. doi: 10.17660/ActaHortic.2013.987.4.

DEVLIN, R. Plant Physiology. New York: D. Van Nostrand Company, 1975. 600p.

EMBRAPA - EMPRESA BRASILEIRA DE PESQUISA AGROPECUÁRIA. Brazilian system of soil classification. Rio de Janeiro: Embrapa, 2006. 306p.

EVANS, J.R. Nitrogen and photosynyhesis in the flag leaf of wheat (Triticum aestivum L.). Plant Physiology, v.72, p.297-302, 1983.

FACHINELlO, J. C. Blueberry. Revista Brasileira de Fruticultura, v.30, n.2, p.285-288, 2008. Available from: $<$ http://www.scielo.br/scielo.php?script=sci_arttext\&pid $=$ S0100-29452008000200001>. Accessed: Apr. 15, 2019. doi: $10.1590 / \mathrm{S} 0100-29452008000200001$

FAQUIN, V. Nutrição Mineral de Plantas. Curso de PósGraduação "Lato Sensu" (Especialização) a Distância: Solos e Meio Ambiente. Lavras: Universitária/UFLA, 2005.

FERREIRA, D. F. Sisvar: a computer statistical analysis system. Ciência e Agrotecnologia, v.35, n.6, p.1039-1042, 2011. Available from: $\quad<$ http://www.scielo.br/scielo.php?script=sci arttext\&pid $=$ S1413-70542011000600001>. Accessed: Apr. 15, 2019. doi: 10.1590/S1413-70542011000600001.

FIELD, C., MOONEY, H. A. The photosynthesis - nitrogen relationship in wild plants. - In: GIVNISH T. J. On the economy of plant form, (Ed.). Cambridge: University Press, 25-53. 1986.

FOLLETT, R. H.; CROISSANT, R.L. Use of manure in crop production. Fort Collins: Colorado State University, 1992. 5p.
FREIRE. C. J. da S. Nutrition and fertilization for blueberries. In: RASEIRA, M. do C.; ANTUNES, L.E.C. The culture of the blueberry. Pelotas: Embrapa Clima Temperado, 2006. p.6074.

GUERRA, A. M. N.; COSTA, A. C. M.; TAVARES, P. R. F. Photosynthetic activity and yield of lettuce grown under shading. Revista Agropecuária Técnica, v.38, n.3, p.125132, 2017. Available from: <https://www.researchgate. net/publication/320552661_Atividade_fotossintetica_e_ produtividade_de_alface_cultivada_sob_sombreamento $>$. Accessed: Apr. 15, 2019. doi: 10.25066/agrotec.v38i3.29246.

GRANATH, G; STRENGBOM, J. Nitrogen fertilization reduces wild berry production in boreal forests. Forest Ecology and Management, p.390:119-126, 2017. Available from: <https:// www.sciencedirect.com/science/article/pii/S0378112716309896>. Accessed: Apr. 15, 2019. doi: 10.1016/j.foreco.2017.01.024.

IFOAM - International Federation of Organic Agriculture Moviments. The world of organic agriculture. Statistics and emerging trends 2017. Available from: https://www.organicworld. Accessed: Sep. 12, 2019.

MIKKELSEN, R.; HARTZ, T.K. Nitrogen sources for organic crop production. Better crops, v.92, n.4, p.16-19, 2008.

MUÑOZ-VEGA, P. et al. Effects of organic fertilizers on the vegetative, nutritional, and productive parameters of blueberries 'Corona', 'Legacy', and 'Liberty'. Chilean Journal of Agricultural Research, v.76, n.2, p.201-212, 2016. Available from: <https://www.researchgate.net/publication/301705057 Effects_of_organic_fertilizers_on_the_vegetative_nutritional_ and productive parameters of blueberries Corona Legacy and_Liberty>. Accessed: Apr. 15,2019 . doi: 10.4067/S071858392016000200010

ROSSI, A. Avaliação bioagronômica de pessegueiro 'Granada' e 'Suncrest' sobre diferentes porta-enxertos. 2004. 76p. Tese (Doutorado) - Universidade Federal de Pelotas, Pelotas.

SANTOS, A. M.; RASEIRA, M. C. B. Growing blueberry Pelotas: Embrapa Clima Temperado, 2002. 17p.

TUCKER, M. Primary Nutrients and Plant Growth. - In: SCRIB, D. (Ed.) Essential Plant Nutrients. North Carolina Department of Agriculture. 2004

YAÑEZ-MANSILLA, E. et al. Photosynthetic and antioxidant performance are differentially affected by short-term nitrogen supply in highbush blueberry cultivars. Ciencia y Investigation Agraria, v.41, n.1, p.61-70, 2014. Available from: <https://www. researchgate.net/publication/265139874 Photosynthetic and antioxidant_performance_are_differentially_affected_by_shortterm_nitrogen_supply_in_highbush_blueberry_cultivars $>$. Accessed:Apr. 15,2019. doi: 10.4067/S0718-16202014000100006. 